\title{
Potassium Organic Salts as Burn Additives in Cigarettes*
}

\author{
by \\ C. Liu and A. Parry \\ British American Tobacco, R\&D Centre, Regents Park Road, Millbrook, Southampton SO15 8TL, United Kingdom
}

\begin{abstract}
SUMMARY
Three potassium salts of organic acids, namely malate, citrate and tartrate, have been sprayed onto flue-cured blend tobacco and subsequently tested for their performance as burn additives in cigarettes. In one experiment where potassium malate was added to vary the final tobacco potassium from ca. $3.1 \%$ to $8.3 \%$ (wet weight), an almost linearly reduction in puff temperature was measured. This was accompanied by a gradual increase in the cigarette's pressure drop. In another set of experiments where the final tobacco potassium contents were increased to ca. $5.1 \%$, the three potassium salts showed almost equal reduction in the mainstream nicotine-free-dry-particulate-matter (NFDPM) at $32-35 \%$, nicotine at $25-32 \%$ and carbon monoxide at 24-35\%. Puff number showed ca. 23\% increase with malate, $13 \%$ with citrate and almost unchanged for tartrate. Evidence of melting and coating by potassium malate was discovered in cigarette ash by scanning electron microscopy (SEM). This contributed to a noticeable change in ash morphology: small ash particles appeared to be coated and more tightly bonded together by the melt. This phenomenon was thought to be able to restrict the airflow during puffing, hence causing the measured increase in pressure drop, and the reductions in puff temperature, NFDPM, nicotine and carbon monoxide. [Beitr. Tabakforsch. Int. 20 (2003) 341-347]
\end{abstract}

\section{ZUSAMMENFASSUNG}

Drei Kaliumsalze organischer Säuren, und zwar Malat, Citrat und Tartrat wurden auf heißluftgetrockneten Blendtabak gesprüht und nachfolgend auf ihre Verwendbarkeit als Brandbeschleuniger bei Zigaretten untersucht. In einem Experiment, bei dem Kaliummalat hinzugefügt wurde, um den endgültigen Kaliumgehalt im Tabak von $3.1 \%$ auf 8.3\% (Feuchtgewicht) zu erhöhen, wurde eine fast lineare Verringerung der Temperatur während des Zuges gemessen. Dies war von einer graduellen Erhöhung des Druckabfalls in der Zigarette begleitet. Bei einer anderen Reihe von Experimenten, bei denen der Kaliumgehalt im Tabak auf ungefähr $5.1 \%$ erhöht wurde, führten die drei Kaliumsalze zu einer fast identischen Verringerung des nikotinfreien Trockenkondensats um $32-35 \%$, von Nikotin um $25-32 \%$ und von Kohlenmonoxid um 24-35\% im Hauptstromrauch von Zigaretten. Die Zugzahl erhöhte sich beim Zusatz von Malat um ungefähr $23 \%$, bei Citrat um $13 \%$ und war bei Tartrat fast unverändert. Durch Untersuchung mittels Raster-Elektronenmikroskopie (SEM) wurden in der Asche von Zigaretten Hinweise auf Schmelz- und Umhüllungsvorgänge gefunden. Dieses Phänomen trug zu einer wahrnehmbaren Veränderung der Morphologie der Asche bei: kleine Aschepartikel schienen umhüllt und durch den Schmelzprozess enger miteinander verbunden zu sein. Es wurde angenommen, dass dieses Phänomen den Luftstrom während des Zuges vermindern könnte und somit zu der gemessenen Erhöhung des Druckabfalls, der Verringerung der Temperatur während des Zuges und der Verringerung des nikotinfreien Trockenkondensats, des Nikotins und des Kohlenmonoxids führen könnte. [Beitr. Tabakforsch. Int. 20 (2003) 341-347]

\section{RESUME}

Trois sels potassiques d'acides organiques, notamment le malate, le citrate et le tartrate ont été ajoutés sur un mélange de tabacs flue-cured et ensuite évalués pour leur emploi comme additifs de combustion dans des cigarettes. Dans une première série d'expériences, où le malate de potassium avait été appliqué pour augmenter la quantité de potassium dans le tabac d'environ $3.1 \%$ à $8.3 \%$ (poids humide), une réduction presque linéaire de la température au cours des bouffées a été mesurée. Ce phénomène a été accompagné par une augmentation graduelle de la perte de charge des cigarettes. Dans une deuxième série d'expériences, où la quantité de potassium dans le tabac avait été augmentée jusqu'à environ $5.1 \%$, les trois sels potassiques ont provoqué dans la fumée du courant principal une réduction presque identique du rendement en matière particulaire anhydre et exempte de nicotine (MPAEN) de 32-35\%, en nicotine de 25-32\% et en monoxyde de carbone de $24-35 \%$. Le nombre des bouffées était augmenté d'environ $23 \%$ en cas d'applica- 


$\begin{array}{lll}\begin{array}{l}\text { Citric acid } \\ \left(\mathrm{C}_{6} \mathrm{H}_{8} \mathrm{O}_{7}\right)\end{array} & \begin{array}{l}\text { Tartaric acid } \\ \left(\mathrm{C}_{4} \mathrm{H}_{6} \mathrm{O}_{6}\right)\end{array} & \begin{array}{l}\text { Malic acid } \\ \left(\mathrm{C}_{4} \mathrm{H}_{6} \mathrm{O}_{5}\right)\end{array} \\ \mathrm{CH}_{2} \mathrm{CO}_{2} \mathrm{H} & \mathrm{CO}_{2} \mathrm{H} & \mathrm{CH}(\mathrm{OH}) \mathrm{CO}_{2} \mathrm{H} \\ \mid \mathrm{C}(\mathrm{OH}) \mathrm{CO}_{2} \mathrm{H} & \mid \mathrm{CH}(\mathrm{OH}) & \mathrm{CH}_{2} \mathrm{CO}_{2} \mathrm{H} \\ \mathrm{CH}_{2} \mathrm{CO}_{2} \mathrm{H} & \mid \mathrm{H}(\mathrm{OH}) & \\ & \mid & \end{array}$

Figure 1. Formulae of the three organic acids used in this work

tion du malate, de $13 \%$ avec du citrate et était presque inchangé avec du tartrate. L'examen de la cendre par microscopie électronique à balayage (SEM) suggère que des fusions et des enrobages soient provoqués par le malate de potassium. Ceci contribue à un changement notable de la morphologie de la cendre: des petits particules de cendres semblent être enrobées et plus fortement liées entre elles par la fusion. On considère que ce phénomène puisse réduire le flux d' air pendant les bouffées et ainsi aboutir à l' augmentation de la perte de charge et à la réduction de la température au cours des bouffées, du rendement en MPAEN, nicotine et monoxyde de carbone. [Beitr. Tabakforsch. Int. 20 (2003) 341-347]

\section{INTRODUCTION}

Early works on adding chemical burn additives to cigarettes to modify the burning temperature involved a wide variety of chemicals $(1,2)$, flame/fire retardants, free radical initiators and inhibitors, salts of organic acids and alkali inorganic salts, etc. Most of them were found to have no significant effect on the burning characteristics of cigarettes even when incorporated at quite high concentrations. In recent years there has been a considerable interest in the effect of potassium organic salts (3-7).

Potassium is a major element of tobacco (up to 10\%) and naturally combines with both inorganic and organic anions (6). YАMАMOTO et al. noticed a link between the potassium contents in bright tobacco with the rate of carbon monoxide formation and the cigarette burning temperature (3). They also established that both exogenous and endogenous (through fertilisation) potassium were equally effective in reducing the "tar", nicotine and carbon monoxide formations in the mainstream smoke, provided the exogenous potassium salts were organic (5). HORLER (6) demonstrated an interacting effect between the inorganic and organic potassium. IZAWA et al. (4) used pyrolysis to explain the mechanisms of potassium malate in modifying the burning characteristics of cellulose. However, their efforts were not conclusive and hindered by a low pyrolysis temperature used $\left(350{ }^{\circ} \mathrm{C}\right)$ : although high enough for the cellulose to dissociate it would not be sufficiently high to explain malate's effects at puffing temperatures. IHRIG and SMITH (7) pointed out that different alkali or alkaline earth metals promoted smouldering to different extents because they have different ionisation energies, and further they achieved this effect by increasing the reactivity of char towards oxygen. However, this could not explain the different activities between alkali inorganic salts and their organic salts.
In summary, the effects of potassium organic acids as burn additives in cigarettes have been studied by many researchers but little is known at present about the mechanisms of their action. In this work, the effects of three potassium organic acid salts (malate, citrate and tartrate) on the mainstream smoke deliveries were measured. Analyses were carried out to understand the mechanism of the potassium salts in modifying burning characteristics of cigarettes.

\section{EXPERIMENTAL}

Aqueous solutions of citric, tartaric or malic acids (their formulae given in Figure 1) were made and mixed with $85 \%(\mathrm{w} / \mathrm{v})$ potassium hydroxide solution to achieve the targeted potassium concentration on a wet weight (w/wt) basis (true for all weight percentage data in this work unless otherwise stated); the concentration/quantity of the acids and the quantity of potassium hydroxide solution were calculated according their reaction schemes (see below) to give designed levels of potassium in tobacco (flue-cured blend).

$\begin{array}{ll}\text { Citric acid (MW 192): } & 3 \mathrm{KOH}+\mathrm{C}_{6} \mathrm{H}_{8} \mathrm{O}_{7}=\mathrm{K}_{3} \mathrm{C}_{6} \mathrm{H}_{5} \mathrm{O}_{7}+3 \mathrm{H}_{2} \mathrm{O} \\ \text { Tartaric (MW 150): } & 2 \mathrm{KOH}+\mathrm{C}_{4} \mathrm{H}_{6} \mathrm{O}_{6}=\mathrm{K}_{2} \mathrm{C}_{4} \mathrm{H}_{4} \mathrm{O}_{6}+2 \mathrm{H}_{2} \mathrm{O} \\ \text { Malic (MW 134): } & 2 \mathrm{KOH}+\mathrm{C}_{4} \mathrm{H}_{6} \mathrm{O}_{5}=\mathrm{K}_{2} \mathrm{C}_{4} \mathrm{H}_{4} \mathrm{O}_{5}+2 \mathrm{H}_{2} \mathrm{O}\end{array}$

The finished solutions had different $\mathrm{pH}$ : approximately 8.5 for the citrate, 7.5 for the tartrate and approximately 7.7 for the malate. More organic acids were therefore added to bring their final $\mathrm{pH}$ to 5.6 in order to match the tobacco blend $\mathrm{pH}$. The precise amounts of the potassium salts formed were calculable but the additional acids added for $\mathrm{pH}$ balance were not recorded. An estimation put the expected cigarette weight gain in the range of $10-15 \%$ compared to their control. The final potassium content of tobacco was analysed by microwave digestion in aqueous nitric acid followed by atomic absorption analysis.

A spray bottle and a cement mixer were used to spray the solutions uniformly onto a flue-cured blend tobacco. Spraying raised the tobacco moisture level to ca. $35 \%$ and this was subsequently reduced to ca. 14-15\%. Spraying also caused some losses in potassium. Filtered cigarettes were manufactured with 80 CORESTA units (CU) cigarette paper and no ventilation. Two sets of experiments were designed: one aimed at comparing the effect of potassium citrate, tartrate and malate at an equal concentration, and the other investigated the effect of a wider range of final tobacco potassium contents, between ca. $3.1 \%$ to $8.3 \%$, sprayed as potassium malate. Physical specifications for all the cigarettes made for the first set of experiments and one cigarette marked as Malate-H from the second set experiments are listed in Table 1 . In Table 1 different cigarette weight gains were obtained relative to the control $(0.884 \mathrm{~g})$, this was caused by the fact that the three potassium salts have different molecular weights as well as different potassium contents in each salt, and also by the combined manufacturing variability. All the cigarettes were conditioned at $22{ }^{\circ} \mathrm{C}$ and $60 \% \mathrm{RH}$ for at least $48 \mathrm{~h}$ before being smoked. 
Table 1. Physical specifications of the cigarettes

\begin{tabular}{lcc|c|c|c}
\hline $\begin{array}{l}\text { Cigarette } \\
\text { Specification }\end{array}$ & Control & Citrate & Tartrate & Malate & Malate-H \\
\hline Total length (mm) & 83.9 & 83.9 & 84 & 84 & 84 \\
Filter length (mm) & 20.2 & 20.1 & 20.3 & 20.1 & 20.0 \\
$\begin{array}{l}\text { Tobacco rod length } \\
(\mathrm{mm})\end{array}$ & 63.8 & 63.9 & 63.7 & 63.9 & 64.0 \\
$\begin{array}{l}\text { Tipping length (mm) } \\
\text { Circumference (mm) }\end{array}$ & 25 & 25 & 25 & 25 & 25 \\
$\begin{array}{l}\text { Cigarette weight (g) } \\
\text { Cigarette pressure }\end{array}$ & 0.884 & 0.959 & 0.909 & 1.005 & 1.018 \\
$\quad 105.9$ & 101.9 & 103.1 & 113.7 & 112 \\
$\quad$ drop (mmWG) & & & & & \\
\hline
\end{tabular}

Note: The pressure drops were measured from unlit cigarettes.

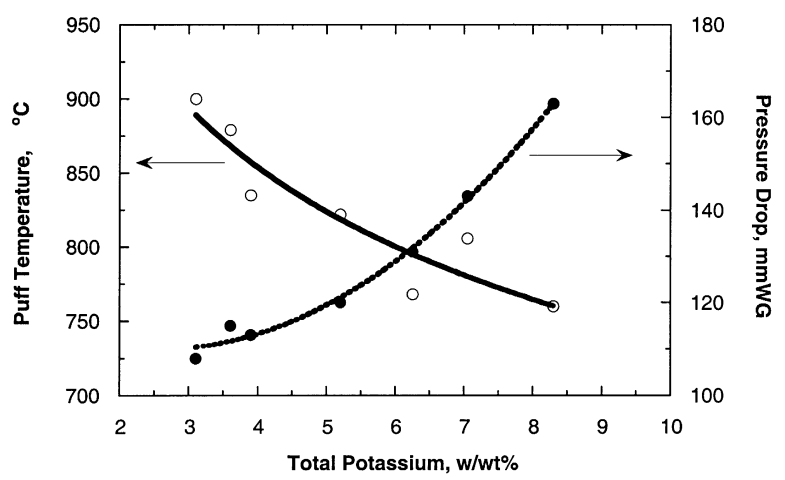

Figure 2. Average puff temperature and extinguished cigarette pressure drop after 3 rd puff plotted against the total tobacco potassium content (in wet weight basis). Cigarettes with added potassium malate.

After smoking the ashes from these potassium-added cigarettes appeared visibly different from the control cigarettes: darker in colour and with higher resistance to breaking. Hence, work was carried out in using a scanning electron microscope (SEM, JEOL5800L) (JEOL UK Ltd, Herts, England) equipped energy dispersive X-ray (EDX) for compositional analysis to examine the cigarette ashes. Ashes from two cigarettes were compared: one with a total $7.05 \%$ potassium and the other the control (Table 1) with $2.95 \%$ potassium. The cigarettes were smoked under the conditions of the International Organisation for Standardisation (ISO) $\left(35 \mathrm{~cm}^{3} / 2 \mathrm{~s} / 60 \mathrm{~s}\right)$ on a single port Borgwaldt smoking machine. Immediately after the second puff each cigarette was extinguished by inserting it into an air-tight glass tube. A $30 \mathrm{~mm}$ long section around the puffed section was cut off from the cigarette. This section was then cut into two equal halves along the longitudinal axis to expose the coal centre for SEM analysis. The ash strength of the potassium malate-added cigarette held the two halves relatively well and this was not the case for the control cigarette. To make the sample electron conductive, the exposed coal centre (one of the halves) was sputter-coated with gold (a standard procedure for analysing less conductive materials under SEM [8]).

Cigarette burning temperatures change dynamically during puffing and depend on measuring technique used (9). In
Table 2. Mainstream smoke chemistry of the cigarettes

\begin{tabular}{l|c|c|c|c|c}
\hline Parameters & Control & Citrate & Tartrate & Malate & Malate-H \\
\hline Potassium (\%) & 2.95 & 5.12 & 5.10 & 5.18 & 7.05 \\
Puff number (per cig) $^{\mathrm{a}}$ & 7.8 & 8.8 & 7.7 & 9.6 & 9.7 \\
TPM $^{\mathrm{b}}$ (mg/cig) & 20.5 & 13.7 & 12.7 & 13.1 & 14.1 \\
Water (mg/cig) $_{\text {Nicotine (mg/cig) }}$ & 3.2 & 1.8 & 1.5 & 1.7 & 1.9 \\
NFDPM (mg/cig) & 1.30 & 0.94 & 0.89 & 0.98 & 1.01 \\
NFDPM:nicotine & 16.1 & 11.0 & 10.4 & 10.5 & 11.2 \\
CO (mg/cig) & 12.4 & 11.7 & 11.7 & 10.7 & 11.2 \\
CO:NFDPM & 16.5 & 12.1 & 10.8 & 12.5 & 13.1 \\
\hline & 1.02 & 1.10 & 1.04 & 1.19 & 1.17 \\
\hline
\end{tabular}

aWet weight basis.

${ }^{\mathrm{b}} \mathrm{TPM}=$ total particulate matter.

Table 3. Levels of reduction (-)/increase (+) in mainstream smoke deliveries

\begin{tabular}{l|c|c|c|c}
\hline Parameters & $\begin{array}{c}\text { Citrate } \\
\text { cf control } \\
(\%)\end{array}$ & $\begin{array}{c}\text { Tartrate } \\
\text { cf control } \\
(\%)\end{array}$ & $\begin{array}{c}\text { Malate } \\
\text { cf control } \\
(\%)\end{array}$ & $\begin{array}{c}\text { Malate-H } \\
\text { cf control } \\
(\%)\end{array}$ \\
\hline Potassium & +74 & +73 & +76 & +125 \\
NFDPM (mg/cig) & -32 & -35 & -35 & -32 \\
CO (mg/cig) & -27 & -35 & -24 & -18 \\
Nicotine (mg/cig) & -28 & -32 & -25 & -31 \\
Puff number (per cig) & +13 & -1 & +23 & +20 \\
NFDPM:nicotine & -6 & -6 & -14 & -1 \\
CO:NFDPM & +7 & +1 & +16 & +20 \\
NFDPM:puff & -39 & -35 & -47 & -43 \\
\hline
\end{tabular}

this work, an infrared camcorder was used to measure the peripheral burning temperature of the cigarettes. Temperatures at each puff were measured by five repeating cigarettes smoked under ISO regime $\left(35 \mathrm{~cm}^{3} / 2 \mathrm{~s} / 60 \mathrm{~s}\right)$.

\section{RESULTS AND DISCUSSION}

\section{Modified burning temperature and mainstream smoke}

A burn additive modifies the combustion conditions inside the cigarette coal and as a consequence alters the mainstream smoke chemistry. The former was clearly shown by the measured burning temperature and the pressure drop of the extinguished cigarettes in Figure 2, both as a function of the total potassium content (raised by adding potassium malate). It seemed that increasing the total potassium content to about $5.2 \%$ resulted in the average combustion temperature being reduced by $75{ }^{\circ} \mathrm{C}$ without significantly increasing the pressure drop. Further increasing the total potassium content caused a greater rise in the pressure drop.

Some mainstream smoke results were obtained and shown in original values in Table 2 and relative changes in Table 3. As mentioned earlier all three potassium-added cigarettes achieved weight gains (Table 1) relative to the control and it seemed appropriate to compare the mainstream deliveries on a per cigarette basis. Tables 2 and 3 showed that the 
a) Magnification: $5250 \times$

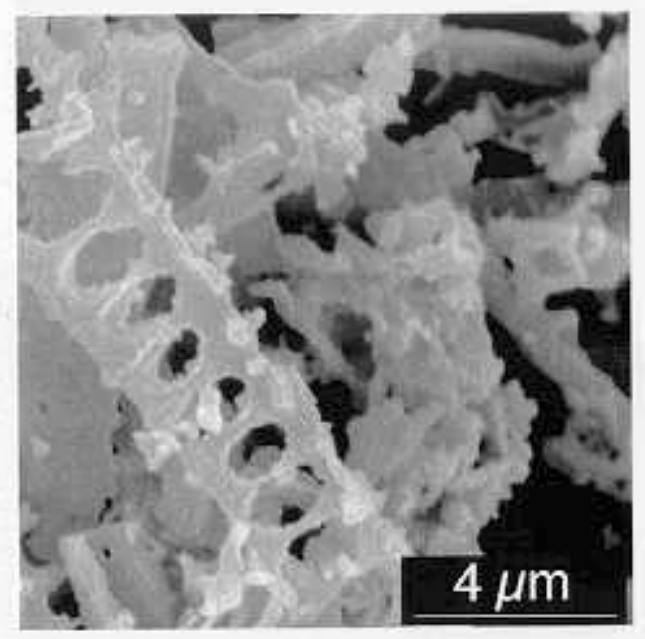

c) Magnification: $400 \times$

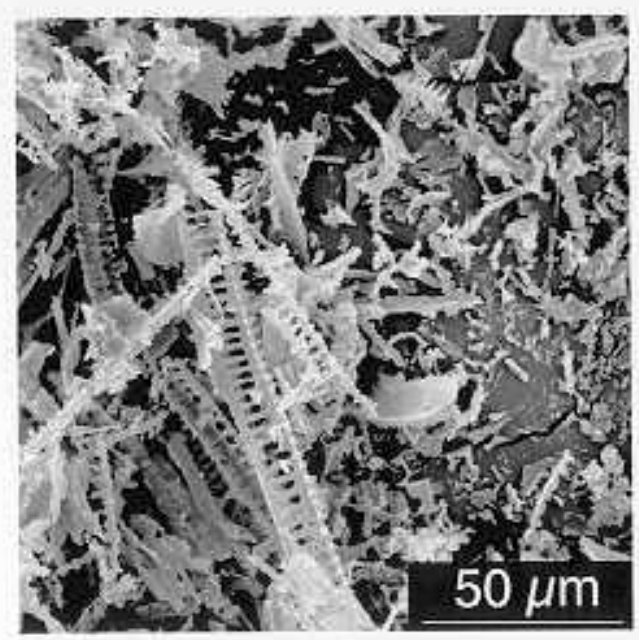

b) Magnification: $2800 \times$

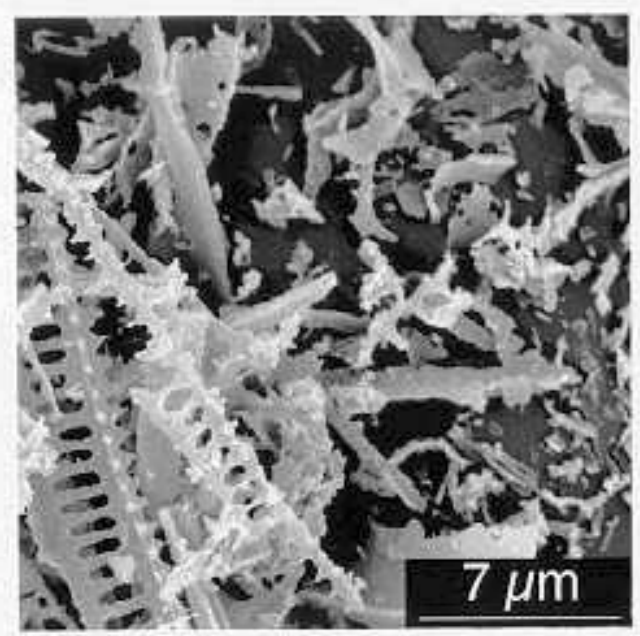

d) Magnification: $120 \times$

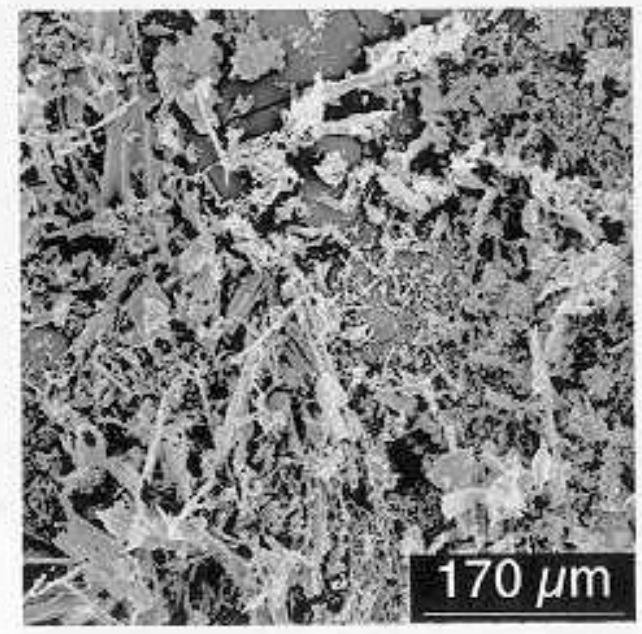

Figure 3. SEM ash morphology of the control cigarette (flue-cured blend with no added potassium organic salt). Four images at progressively lower magnifications.

three potassium salts gave similar reductions in NFDPM (approximately $33 \%$ per cigarette and approximately $40 \%$ per puff), nicotine (approximately 27\%) and CO (approximately 27\%). The malate cigarettes achieved the highest reduction in NFDPM:nicotine ratio at $14 \%$, more than twice those of the citrate and tartrate cigarettes. On per unit NFDPM basis, the malate cigarettes produced the highest increase in $\mathrm{CO}$ at $16 \%$, followed by the citrate cigarettes at $7 \%$ whilst the tartrate cigarettes were almost unchanged. At the same time puff number was increased by $23 \%$ for the malate, $13 \%$ for the citrate but was unchanged for the tartrate. The tartrate-added cigarettes were the only type that maintained the puff number yet delivered an effective reduction in NFDPM, nicotine and CO (Table 3 ).

Tables 2 and 3 also showed that for the malate-added cigarettes the effectiveness in the mainstream reduction became decreased when potassium contents were further increased to beyond ca. 5.1\%. However, there was another possibility: as the cigarettes containing potassium malate were produced by two different batches (one batch with the citrate and the tartrate, and the other malate itself varying from ca. $3.13 \%$ to $8.29 \%$ ), therefore this differences in the effectiveness of the malate need further investigation.

\section{SEM/EDX analysis}

A significant increase in pressure drop was noted in this work on both lit and extinguished cigarettes, particularly for the potassium malate-added cigarettes. This, combined with a darker ash appearance, strongly indicated that both microscopic and macroscopic features of the ash were modified by the presence of the potassium salts, possibly by a melt or foam formed at the puff temperature. It was therefore decided to use SEM/EDX to compare the ash morphologies of the malate-added cigarette with a $7.05 \%$ of total potassium with that of the control cigarettes with no added potassium malate. Details about the ash sample preparation were described in the experimental section.

To make use of the high spatial resolution of SEM and at the same time, more importantly, to gain a representative view of each sample, at least three areas from the ash sample were randomly selected and examined at four different magnifications. Examples of the SEM ash morphologies from the control cigarette and the $7.05 \%$ potassium (malate-added) were shown in Figures 3 and 4, respectively.

Comparing Figure 3 with Figure 4, it was clear that the microscopic features from the two cigarette ashes were 
a) Magnification: $2800 \times$

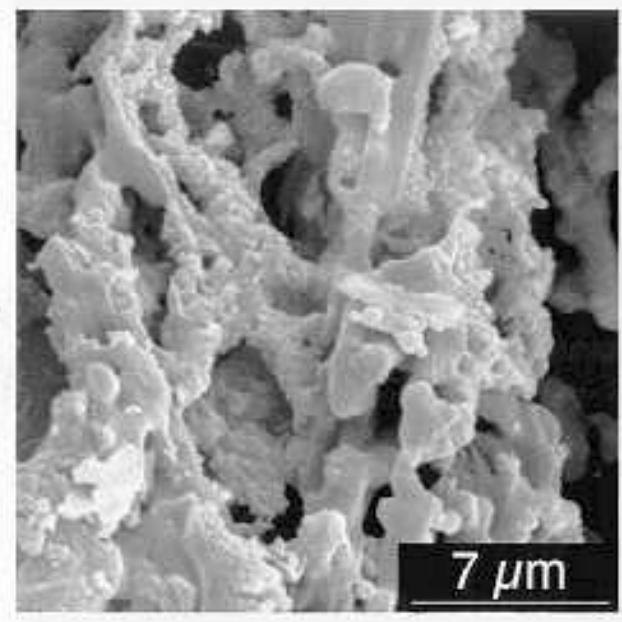

c) Magnification: $600 \times$

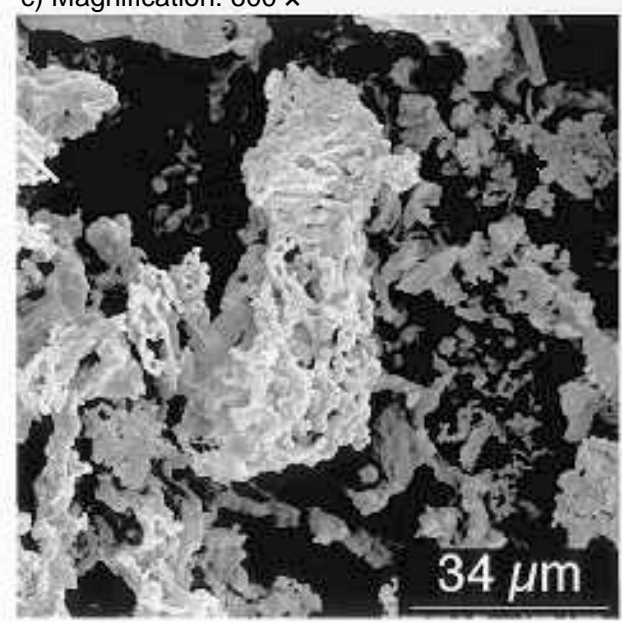

b) Magnification: $1300 \times$

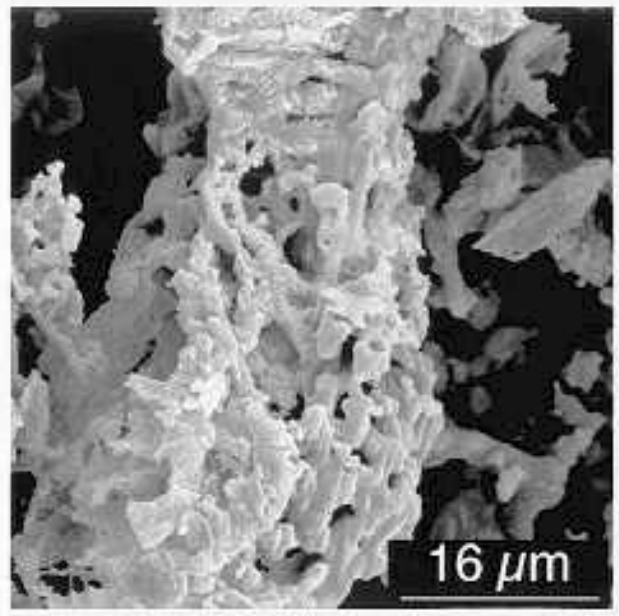

d) Magnification: $300 \times$

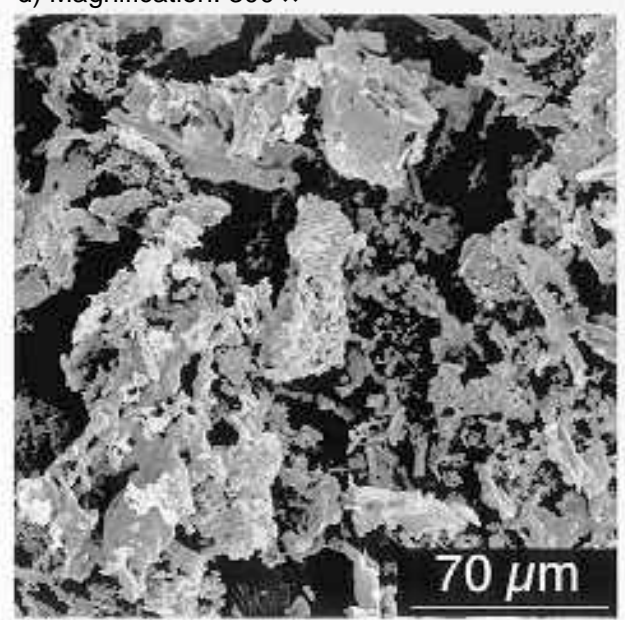

Figure 4. SEM ash morphology from a malate-added cigarette with a total of $7.05 \%$ potassium. Four images at progressively lower magnifications.

distinctively different. The ash from the control cigarette (Figure 3) appeared to be more plant structure-like with more sharper, broken particles or branches; whereas the ash from the malate-added cigarette appeared to be more rounded, connected (or "sticky") and lost its plant structural features (Figure 4).

This distinction was consistent on all the magnifications in Figures 3 and 4 (and also other areas examined but not shown). In general, the well connected ash branches with circular melt particles (Figure 4) were only seen in the $7.05 \%$ potassium (malate) cigarette ash, but ash with plant structure features existed on both samples.

In Figure 5 two ash branches with smoother surface from the two cigarettes are compared, the control cigarette on the left (Figure 5a) and the malate-added on the right (Figure $5 b$ ). Extensive spherical or semi-spherical nodules of quite regular and uniform features were clearly seen from the malate-added cigarette (Figure 5b); the extent of this feature was much less pronounced on the control cigarette ash (Figure 5a). The relatively flat background permitted these semi-spherical nodules to be analysed by EDX for any compositional difference. Three nodular spots marked by $\mathrm{A}, \mathrm{B}$ and $\mathrm{C}$ were selected and their corresponding EDX spectra were given in Figure 6 (only one each was shown). In every spot analysed from the malate-added cigarette ash, a significantly higher potassium peak was detected as compared to the control ash by EDX (Figure 6). This result confirmed that the nodules were associated with the added potassium malate after the tobacco carrying it was burnt by puffing.

The round, well-defined nature of these nodules suggested that they were most likely formed by melting and cooling of malate salt. On a relative flat surface, the melts probably strengthened the branch from dissociating physically into smaller pieces (Figure 5b); if the melts were formed between branches, they were better connected and less easy to break (Figure 4).

No SEM/EDX analysis were performed on ashes produced during smouldering, so it was not clear whether melting of potassium malate only occurred during puffing. It was also not clear whether similar observation existed on the citrateor tartrate-added cigarettes. Nevertheless, it seemed highly plausible that the melted patches at puff temperature caused less ash particles being generated and to contribute to the 
Magnification: $1100 \times$

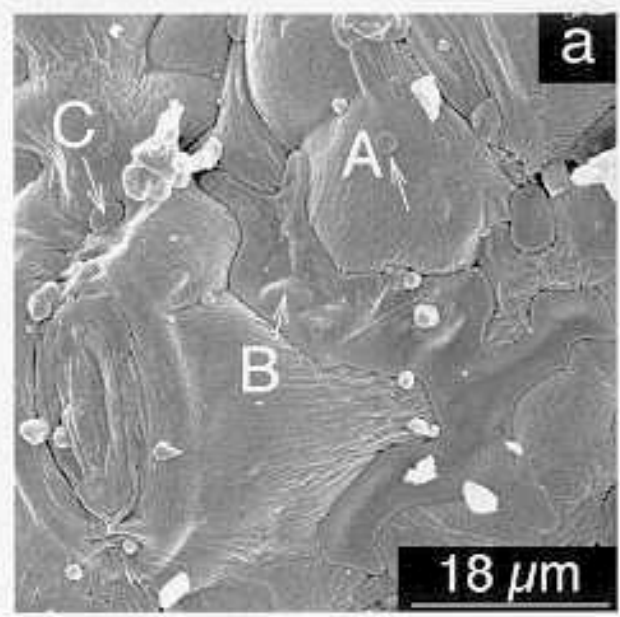

Magnification: $2500 \times$

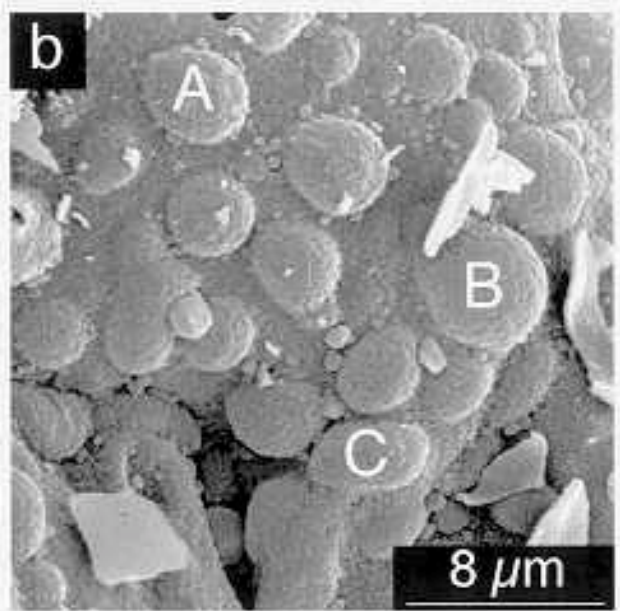

Figure 5. Two SEM micrographs from the control cigarette (the left image) and the malate-added cigarette (the right image). Markers (A, B and C) indicate the areas where EDX spectra were obtained (Figure 6).
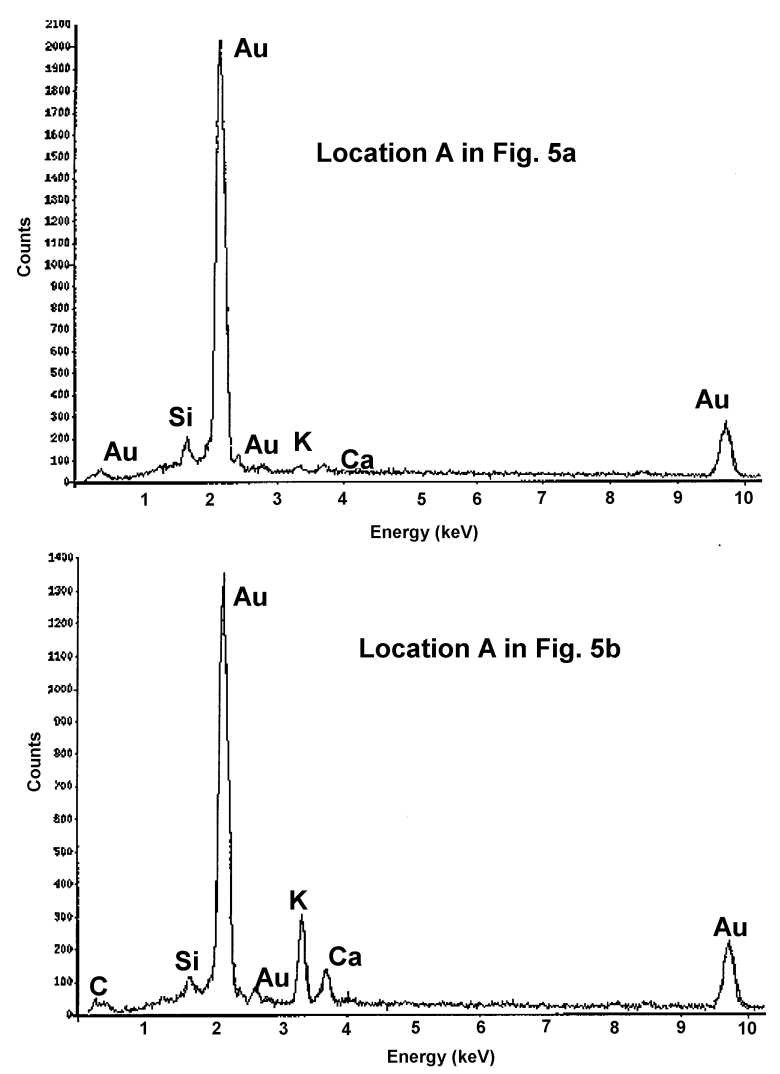

Figure 6. Two examples of EDX spectrum from the areas marked in Figure 5. One spectrum for each sample (location A) is shown and the spectra from $B$ and $C$ are qualitatively similar.

smoke formation (hence the mainstream TPM reduction), and possibly restricted the air flow inside the cigarette coal (hence the reduced burning temperature and the increase in pressure drop). This all contributed to the reduced formation of TPM and the higher pressure drop. It was also possible that chemical interactions played a role in decreas- ing the thermal activity and subsequent fragmentation of tobacco ash (6), this could account for the differences noted between the three potassium salts.

\section{CONCLUSIONS}

The potassium organic salts tested in this work significantly modified the burning of cigarettes and reduced some of the mainstream smoke constituents. More specifically,

- Adding potassium as malate, citrate and tartrate to tobacco at ca. $5 \%$ total level had a similar overall effects per cigarette, with only the tartrate-added cigarettes maintained the puff number and the carbon monoxide yield (on per unit NFDPM basis)

- One (possibly the main) mechanism of combustion modification in the case of malate was the melting of potassium-rich substances, which altered the ash morphology in a way that restricted the air flow and caused stronger bonding of the ash particles.

Acknowledgement: M.V.G. Pereira (BAT, Souza Cruz, Brazil) obtained the cigarette's burning temperature and pressure drop data in Figure 2. Drs. R.R. Baker, G. Kijowski and K. McAdam (BAT, Southampton, UK) commented on the original manuscript.

\section{REFERENCES}

1. Miller, F., W.J. Freeman and R.L. Stedman: The effect of additives on the combustion temperature of cigarettes; Beitr. Tabakforsch. 4 (1968) (7) 269-274.

2. Terrel, J.H. and I. Schmeltz: Alteration of cigarette smoke composition: I. Influence of certain additives; Tob. Sci. 14 (1970) 78-81.

3. Yamamoto, T., Y. Suga, K. Kaneki and H. Kaneko: Effect of chemical constituents on formation rates of carbon monoxide of bright tobacco; Beitr. Tabakforsch. 
14 (1989) 163-170.

4. Izawa, K., M. Matsukura and Y. Ishizu: Curie-point pyrolysis of cellulose in the presence of potassium malate; Agric. Biol. Chem. 54 (1990) 957-963.

5. Yamamoto, T., S. Umemura and H. Kaneko: Effect of exogenous potassium on the reduction in tar, nicotine and carbon monoxide deliveries in the mainstream smoke of cigarettes; Beitr. Tabakforsch. Int. 14 (1990) 379-385.

6. Horler, J.W.: Organic potassium: its role in controlling the rate of burn and tar content of tobacco products; $47^{\text {th }}$ Tobacco Chemists Research Conference, October 1993, Program Booklet and Abstracts, Paper No. 26, 1993.

7. Ihrig, A.M. and S.I. Smith: The role of alkali and alkaline earth metal ions in cellulosic smouldering; J. Fire Sci. 12 (1994) 357-375.
8. Goldstein, J.I., D.E. Newbury, D.C. Joy, C. Fiori and E. Lifshin: Scanning electron microscopy and X-ray microanalysis; Plenum Press, New York, 2nd Ed., 1984.

9. Baker, R.R.: Temperature distribution inside a burning cigarette; Nature 247 (1974) 405-406.

Address for correspondence:

Chuan Liu

British American Tobacco,

$R \& D$ Centre

Regents Park Road

Millbrook, Southampton SO15 8TL

United Kingdom 